\title{
Reconstruction of the Trochlear Sulcus Using a Cartilage Flap from the Lateral Condyle of the Femur in a Dog with Medial Patellar Luxation
}

\author{
Katsuyoshi NAGAOKA, Toshifumi KOSAKA*, Yoshiyuki YAMAYA*, \\ and Shigeo TANAKA* \\ 大腿骨外側顆を軟骨弁として利用し大腿骨滑車を再建した \\ 犬の膝蓋骨内方脱臼の 1 例 \\ 永岡勝好, 小坂俊文 ${ }^{*}$, 山谷吉樹 ${ }^{*}$, 田中茂男 ${ }^{*}$
}

[平成 9 年 6 月 23 日受付 /平成 10 年 1 月 15 日受理〕

\begin{abstract}
SUMMARY
Surgical treatment was tried in a dog with medial patellar luxation in which trochleoplasty had been unsucsessfully done twice in the past. The trochlear sulcus was erosive and covered with the inflammatory tissues. Patella luxation was treated by reconstructing the trochlear sulcus using a cartilage flap obtained from the lateral condyle of the femur, combined with correction of the alignment of the soft tissue from the rectus femoris muscle to the tibial crest. This procedure allowed the trochlear to be covered with the new hyaline cartilage. Excellent function was restored in about 3 months after surgery. Therefore, it was considered that this surgical technique could be an effective reconstructive method of the trochlear cartilage before considering the adaptation of arthrodesis.
\end{abstract}

Key words : dog, patella medial luxation. trochleoplasty

In veterinary practice, medial patella luxation (MPL) has been frequently observed in toy or miniature breed dogs, such as Miniature and Toy Poodles, Pomeranians, York-

日本大学生物資源学部附属アニマルメディカルセン 夕一, * * 獣医外科学研究室 (下 252 神奈川県藤沢 市亀井野 1866)

Animal Medical Center, and Laboratory of Veterinary Surgery, Department of Veterinary Medicine, College of Biological Resource Science, Nihon University. 1866 Kameino, Fujisawa, Kanagawa, 252, Japan shire Terriers, Pekingese ${ }^{5,9)}$. Patella luxation is classified into four grades according to the degree of patella displacement and the abnormality of the femorotibial joint ${ }^{11}$. Many surgical techniques for canine patellar luxation have been developed, such as imbrication capsulectomy $\mathrm{y}^{2,8)}$, trochlear wedge recession ${ }^{1,10)}$, trochleoplasty ${ }^{4,7,14)}$, tibial crest transposition $^{4,7,14)}$. However, degenerative joint disease (DJD) might occur after some of these surgical treatments depending on the patient's 

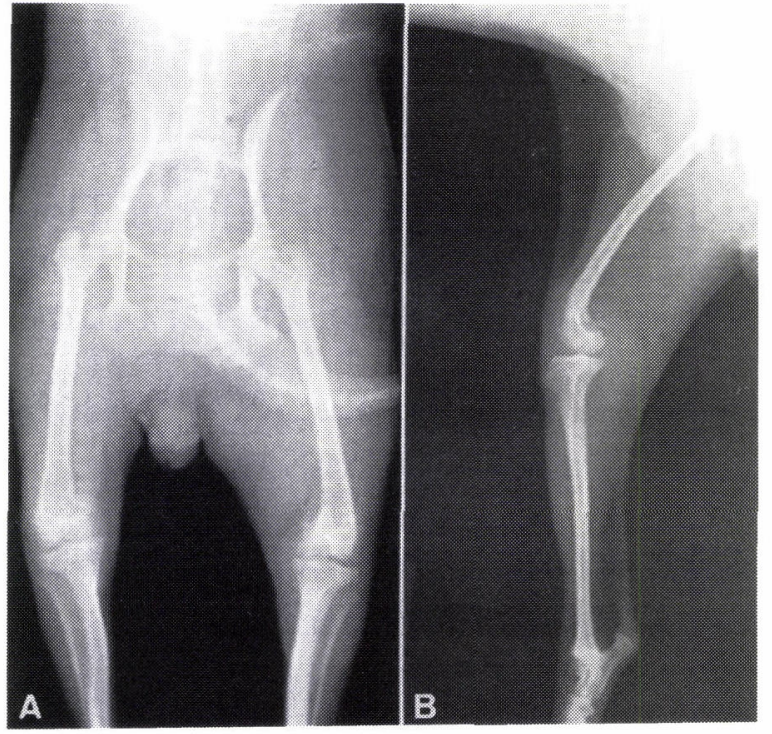

Fig. 1. Preoperative radiographs of the stifle joint.

condition, or the failure of the surgical technique and/or postoperative care $^{15)}$. Mild DJD was evident in all the stifle joint and only 4 of 34 dogs were lame at follw-up ${ }^{15)}$. In a retrospective study of 82 dogs with surgical correction of patella luxation, remarkable postoperative results were obtained after trochlear deepening with cartilage ${ }^{6)}$. In some cases with DJD after surgical operation for MPL, the patient showed various postoperative complications including lameness, arthralgia, arthrocele, joint function disorder, arthrogryposis. Moreover, it was found that the range of motion was decreased in most of these cases. The reconstructive surgery after the failure of trocleoplasty was very difficult on account of the insufficient formation of trochlear cartilage or hyperplastic tissues, and arthrodesis was often indicated in these cases.

We tried to make a surgical treatment for the case, in which trochleoplasty had ended in failure, by reconstructing the trochlear sulcus using a cartilage flap obtained from the lateral condyle of the femur.

A $1.4 \mathrm{~kg}$, one-year-old, female Pomeranian was presented to the Nihon University Animal Medical Center. The patient had received trochleoplasty twice for the restoration of MPL in the right hind limb. At the first admission, the case showed disuse and lameness and kept a flexed position in the affected limb. By palpation, the patient showed severe pain in the flexural movement of the stifle joint with muscular atrophy. On radiography at the admission (Fig. 1), the right femorotibial joint was laterally inclined, and the distal part of the femur was abducted. The patella was displaced medially, and the tibia was adducted. The findings indicated an obvious weight bearing on the inside, and also the hyperplasia of the articular capsule was recognized with medial and lateral aspect of the stifle joint. Moreover, radiolucency was found in the patella and the trochlear ridge, and a decrease of bone 


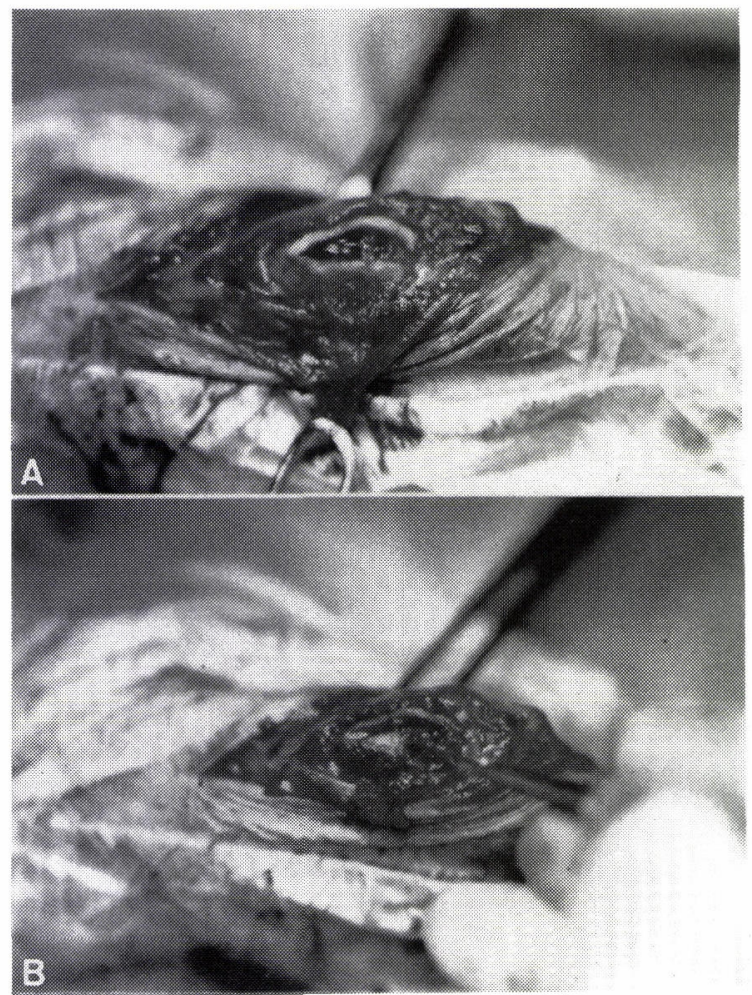

Fig. 2. The deepened trochlear sulcus with hyperplasia of the synovium was confirmed at the time of surgery.

A: The subchondral bone was deeply shaved with ulcerative inflammation.

B: A fibrocartilagious tissue was not found on the subchondral bone of the trochlear sulcus.

density was also recognized. From these findings, MPL of the case was diagnosed as grade 2 by Singlton's grading system. Surgical treatment was selected for this case to improve the articular congruity of the femoropatellar joint and to reduce the alignment from the quadriceps muscle to the tibial crest.

Atropine sulfate $(0.02 \mathrm{mg} / \mathrm{kg})$ and acepromazine maleate $(0.025 \mathrm{mg} / \mathrm{kg})$ were given subcutaneously for premedication. A mixed solution of ketamine hydrochloride $(5 \mathrm{mg} /$ $\mathrm{kg})$ and a flunitrazepam $(0.1 \mathrm{mg} / \mathrm{kg})$ were administered intravenously for induction.
After tracheal intubation, general anesthesia was maintained with the inhalation of isoflurane. Respiration was controlled by mechanical ventilation with a maximum airway pressure in $15 \mathrm{cmH}_{2} \mathrm{O}$ and respiratory rate in 4 times a minute, respectively. Operative field of the stifle joint was disinfected after cripping by the routine manner.

A cranio-medial skin incision was made from the center of the femur to the proximal $1 / 3$ of the tibia. After separation of the subcutaneous tissue, the articular capsule was incised at the same position. The 


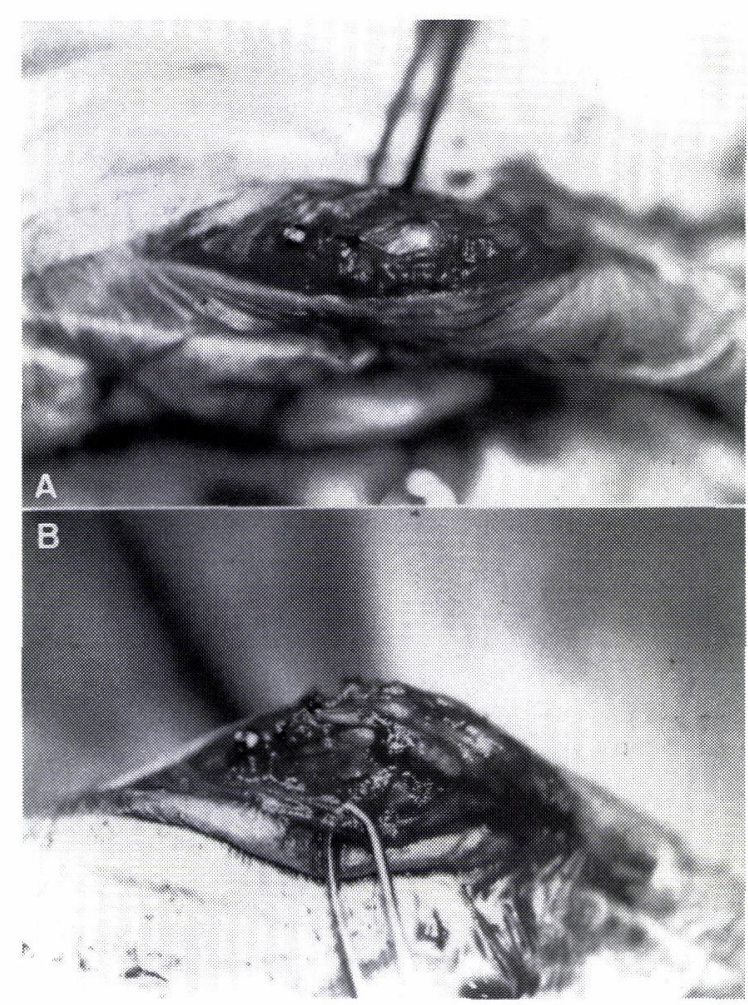

Fig. 3. Reconstruction of the trochlear sulcus.

A : A cartilage flap prepared from the lateral condyle of the fumer was bent medially to cover the deepened trochlear sulcus.

B : A bone screw was inserted from the medial trochlear ridge of the femoral bone to the cortical bone of the opposite side.

articular capsule was incised parallel to the patella and then the patella was dislocated laterally. It was confirmed that the subchondral bone of the trochlear sulcus had been undermined deeply and ulcerative inflammation was recognized (Fig. 2). The fibrocartilaginous tissue was not found on the subchondral bone of the trochlear sulcus (Fig. 2 b). A gap between the patella and the trochlear sulcus was recognized when the patella was reduced on the trochlear sulcus. Intra-articular cavity was irrigated with sterile saline and the inflamed synovial tissue was completely removed. For restoration of the trochlear sulcus, the inflamed subchondral bone was shaved using an osteotome until a fresh normal bone tissue appeared. For preparation of the cartilage flap, the cancellous bone of the lateral condyle of the femur was eliminated to the lateral trochlear ridge in a parallel fashion. The eliminated cancellous bone was restored and transplanted on a fresh wound of the trochlear sulcus, then the cartilage flap was medially bent to cover the trochlear sulcus (Fig. $3 \mathrm{a}$ ). Thus, 


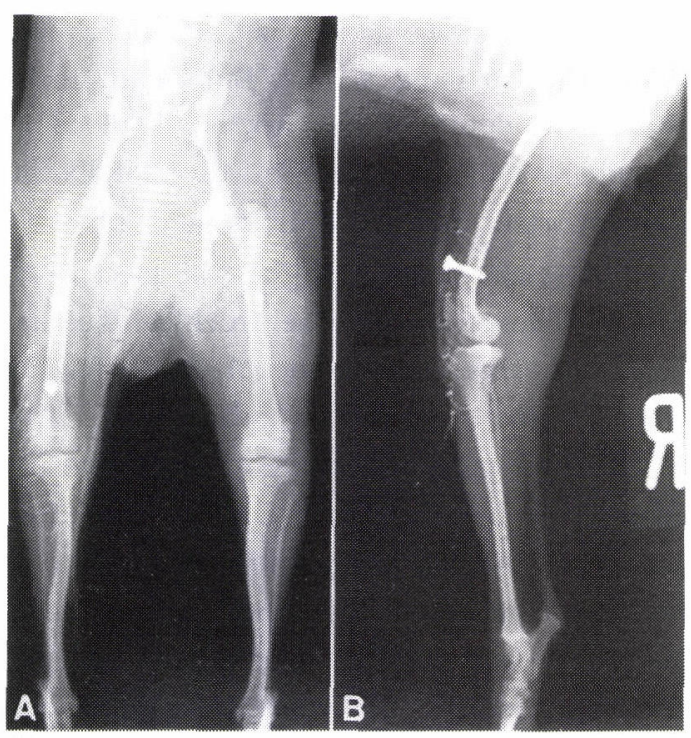

Fig. 4 Radiographs immediately after surgery. A : Anterior-posterior image.

B : Lateral image.

the trochlear sulcus was reconstructed with the hyaline cartilage. The depth of the trochlear sulcus was adjusted to about a half thickness of the patella. The reconstruction of the soft tissue including the quadriceps muscle group was aligned with the patella at the top of the trochlear. After separation of the lateral articular capsule, a 2-3 $\mathrm{mm}$ of the lateral articular capsule was resected parallel to the patella. This incision was extended between the vastus lateralis muscle and the rectus femoris muscle. The stifle joint was held in a position of about 140 degrees, and the patella was fixed tentatively at the top of the trochlear. The lateral articular capsule was sutured using absorbable sutures between the lateral articular capsule and the patella lateral retinaculum attachment. It was retained in a position where the patella was made stable in accordance with a flexing and

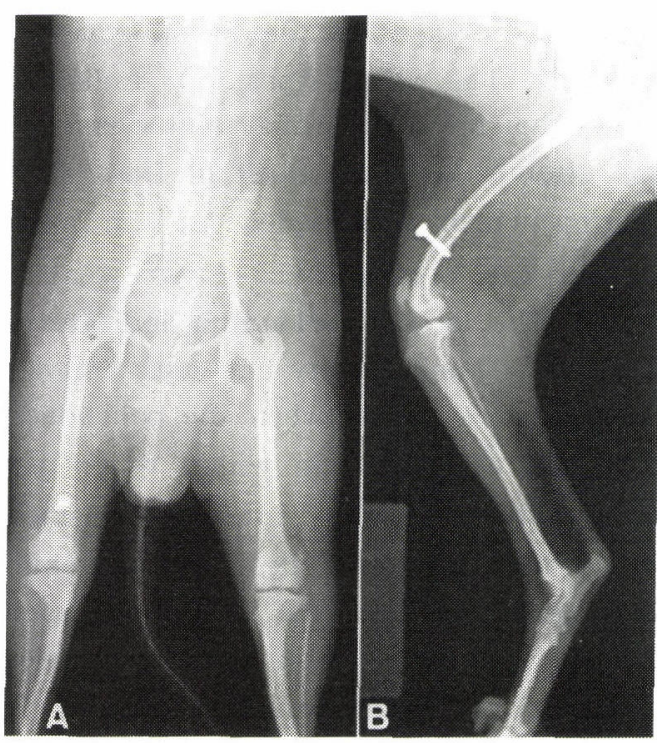

Fig. 5. Radiographs at the 90th day A : Anterior-posterior image. B : Lateral image.

stretching exercise of the stifle joint, and the lateral articular capsule was closed by the imbrication technique. Medial release was also made in the medial articular capsulle. A bone screw was inserted from the medial trochlear ridge of the femoral bone to the cortical bone of the opposite side (Fig. 3 b). The screw head was kept to protrude about $5 \mathrm{~mm}$ from the bone surface, and stabilized the alignment of the rectus femoris muscle and the patella, which also prevented medial displacement of the patella. The subcutaneous tissue and skin were closed using a routine method.

The postoperative radiograph is shown in Fig. 4. In the anterior-posterior radiograph, it was confirmed that the alignment between the tibia and patella was corrected, and the femorotibial joint became almost normal angle. In the lateral radiograph, the patella was in normal position. Figure 5 
shows radiographs at the 90 th postoperative day. The anterior-posterior radiograph shows that the femorotibial joint was in normal straight angle, suggesting that weight bearing which was loaded on the medial site in the preoperative status was corrected. The lateral radiograph indicates an increase of bone density and consistency of the patella. A gap between the subchondral bone and cartilage flap which was clearly recognized immediately after the operation was buried and remodelled. The anatomical alignment including the trochlear groove, quadriceps muscle group, patellar ligament, and tibial tuberosity, was also repaired. The affected limb was grounded on the 4 th postoperative day, and weight bearing was initiated on the 5 th postoperative day. The swelling of the surgical wound disappeared on the 8th postoperative day, and gait was remarkably improved. The gait of the affected limb became normal on the 30th postoperative day, and running became possible on the 60th postoperative day. Genu varum was corrected on the 90 th postoperative day.

Various surgical techniques have been reported for congenital medial patella luxation in dogs. The surgical techniques were applied in accordance with the classification by Singleton. The purpose of all these techniques is reconstruction of the extensor function of the stifle joint by aligning the quadriceps muscle group, patella, trochlear groove, patellar ligament, and tibial tuberosity. For the case with the shallow trochlear sulcus, the trochlear wedge recession or the trochlear chondroplasty are usually indicated. The former is applied mainly for adult dogs, the latter for puppies under 6 months old, respectively.
However, trochleoplasty is an operation where the cartilage is lost. But in all techniques, the depth of the trochlear sulcus is roughly a half thickness of the patella. It was reported that continuous and physiologic pressure of the patella was necessary for the regeneration of the trochlear sulcus. This case received trochleoplasty twice in other animal hospitals. However, the subchondral bone was causing ulcerative inflammation because there was no proliferation of the fibrous connective tissue. It was possibly considered that the gap between the patella and the trochlear sulcus became too wide, because the trochlear sulcus was shaved too deeply and the proliferation of fibrous connective tissue or fibrocartilaginous tissue was not obtained. In such a case, arthrodesis is sometimes reluctantly carried out as a rescue treatment of the hind limb function. In this paper, we reported a new reconstructive technique in which the cartilage flap obtained from the lateral femoral condyle was used as the trochlear cartilage. Reconstructive technique for the trochlear cartilage like this has not been reported. A characteristic of this method was covering the trochlear sulcus with a cartilage flap, which is made from the hyaline cartilage. It was considered that this new technique had similar results to a trochlear wedge recession. This surgical technique should be adapted in combination with the other reconstructive techniques for the soft tissue. A bone screw was inserted into the femoral medial trochlear ridge to stabilize the alignment of the rectus femoris muscle and patella. The bone screw that was inserted into the femur directly rubbed with the inside of the rectus femoris muscle tendon, but inflammation and pain were not 
recognized during postoperative observation. Although a lateral condyle of the femur was reduced by this surgery, the patella did not cause medial or lateral luxation. As the result, the patella was fitted with the new trochlear sulcus. Moreover, it is conceivalbe that this surgical technique could be regarded as an effective reconstruc-

tive method of the trochlear cartilage before considering the adaptation of arthrodesis.

\section{要 約}

膝蓋骨内方脱臼に対する滑車溝形成術を過去に 2 回受けた体重 $1.4 \mathrm{~kg}, 1$ 歳のポメラニアンが, 患肢の疼痛, 跛行を主訴として来院した。X 線 検査により膝蓋骨内方脱臼の再発が発見され，再 度外科的治療を試みた。術中所見として, 大腿骨 滑車領域の軟骨下骨は深く削られており，潰瘍性 炎症を生じていた。この症例に対して，大腿骨外 側顆を軟骨弁として利用した滑車溝再建術，およ び大腿四頭筋の整復術を行った。術後 90 日目ま での術後経過は良好であり, 本手術方法は, 関節 固定術の適用を考慮する以前の新しい滑車軟骨の 再建術として有用と考えられた。

\section{References}

1) Boone, E.G., Hohn, R.B., and Weisbrode, S.E. (1983) : Trochlear recession wedge technique for patellar luxation : An experimental study. J. Am. Anim. Hosp. Assoc. $19: 735-742$.

2) Campbell, J. R. and Pond, M. J. (1972): The canine stifle joint. II. Medial luxation in the dog. Vet. Med. Small. Anim. Pract. 13 : 11-18.

3) Hulse, D. A. (1981) : Pathophysiology and management of medial patellar luxation in the dog. Vet. Med. Small Anim. Clin. $76: 43-51$.
4) Hulse, D. A., Miller, D., Roberts, D., Shires, P., and Shoji, H. (1986) : Resurfacing canine femoral trochleoplasties with free autogenous periosteal grafts. Vet. Surg. $15: 284-288$.

5) Knight, G.C. (1963) : Abnormalities and defects in pedigree dogs. III. Tibiofemoral joint deformity and patella luxation. J. Small Anim. Pract. 4 : 463-???.

6) Matis, U. and Fritz, R. (1990) : Longterm results of surgical treatment. Vet. Comp. Orthop. Traumatol. $3: 39$.

7) Moore, J. A. and Banks, W. J. (1989): Repair of full-thichness defects in the femoral trochlea of dogs after trochlear arthroplasty. Am. J. Vet. Res. 50 : 1406 1413.

8) Palumbo, N.E. (1971): A new technique for repair of canine patellar luxations. Mod. Vet. Pract. 52 : 51-53.

9) Priester, W. A. (1972) : Sex, size, and breed as risk factors in canine patellar dislocation. J. Am. Vet. Med. Assoc. 160 : $740-742$.

10) Richards, C.D. (1975) : Surgical correction of medial patellar luxation : Tibial crest transplantation and trochlear arthroplasty. Vet. Med. Small. Anim. Clin. $70: 322-325$.

11) Roush, J. K. (1993) : Canine patellar luxation. Vet. Clin. North Am. Small Anim. Prac. $23: 855-868$.

12) Singleton, W.B. (1969) : The surgical correction of stifle deformities in the dog. J. Small Anim. Pract. 10 : 56-69.

13) Slocum, B. and Devine, T. (1985): Troc hlear recession for correction of luxating patella in the dog. J. Am. Vet. Med. Assoc. 186 : 365-369.

14) Vaughan, L. C. and Robins, G. M. (1975): Surgical remodelling of the femoral tro- 
chlea : An experimental study. Vet. Rec. $96: 447-450$.

15) Willauer, C. C. and Vasseur, P. B. (1987):
Clinical results of surgical correction of medial luxation of the patella in dogs. Vet. Surg. $16: 31-36$. 